\title{
Konstruksi Model Manajemen Mutu Syariah Dalam Pengelolaan Zakat di Baznas Provinsi Jambi
}

\author{
Muhammad Zaki \\ Institut Agama Islam Yasni Bungo Jambi \\ Email: mdzakiismail@gmail.com \\ Amiur Nuruddin \\ Universitas Islam Negeri Sumatera Utara \\ Email: amiurstbatuah@yahoo.com \\ Saparuddin Siregar \\ Universitas Islam Negeri Sumatera Utara \\ Email:saparuddinss@yahoo.com
}

\begin{abstract}
Zakat as a fundamental obligation, has certain uses according to the sharia. It's doesn't only have the purpose of worship, but also aims to realize social and economic functions in Islamic society. The managerial revitalization of zakat institutions and fulfilled quality management standards becomes very important, in order to gain trust from the public and achieve the objectives of zakat, and must also be based on sharia values and frames (comply to sharia principles). This research aims to construct a quality management model for BAZNAS Jambi Province based on sharia values. This research uses a qualitative method through a library approach. The data used in this study are secondary data in the form of literature and documentation, which are then analyzed through descriptive methods. The construction of this model is needed in order to develop and strengthen the presence of Islamic economics, especially in the field of management through continuous research.
\end{abstract}

Keywords: Zakat, Management, Quality, BAZNAS

\begin{abstract}
Abstrak
Zakat sebagai suatu kewajiban yang mendasar, memiliki penggunaan tertentu menurut ukuran yang telah diatur oleh syariat. Selain memiliki tujuan ibadah, zakat juga bertujuan untuk merealisasikan fungsi-fungsi sosial dan ekonomi dalam masyarakat Islam. Revitalisasi manajerial lembaga zakat ke arah yang lebih baik dan memenuhi standar manajemen mutu menjadi sangat penting, agar mendapat kepercayaan dari publik dan tercapainya tujuan pensyariatan zakat, dan juga harus berdasarkan pada nilai-nilai dan bingkai syariah (comply to syariab principles). Penelitian ini bertujuan untuk mengkonstruksi model manajemen mutu bagi BAZNAS Provinsi Jambi berdasarkan pada nilai-nilai syariah. Penelitian ini menggunakan metode kualitatif melalui pendekatan kepustakaan. Data yang digunakan dalam kajian ini
\end{abstract}

Nur El-Islam, Volume 6, Nomor 2, Oktober 2019 
merupakan data sekunder dalam bentuk literatur dan dokumentasi, yang kemudian dianalisa melalui metode deskriptif. Konstruksi model ini diperlukan dalam rangka membangun, mengembangkan dan memantapkan keberadaan ilmu ekonomi Islam, terutama dalam bidang manajemen melalui penelitian yang terus menerus.

Kata kunci: Zakat, Manajemen, Mutu, Syariah, BAZNAS.

\section{A. Pendahuluan}

Islam menekankan agar segala sesuatu harus dikerjakan dan dikelola dengan tepat, tertib, rapi dan benar. Seluruh prosedur yang ditetapkan harus diikuti dan sesuatu tidak dapat dikerjakan dengan melanggar aturan. ${ }^{1}$ Dalam pengertian lain, Islam menghendaki agar seluruh pekerjaan dilakukan dengan manajemen atau aturan yang terarah dan terukur untuk mendapatkan hasil yang maksimal. Praktek manajemen telah mendapat perhatian di dalam Islam sejak zaman Rasulullah saw. sampai kepada zaman ke-khalifahan. Manajemen yang bermakna pengelolaan atau pengurusan terhadap organisasi digunakan di dalam berbagai aspek kehidupan seperti berdakwah, berbisnis, berpolitik, militer, dan kehidupan sosial lainnya.

Pemikiran manajemen dalam Islam bersumber dari nash-nash Alquran dan petunjuk-petunjuk sunnah. Selain itu, ia juga berasaskan pada nilai-nilai kemanusiaan yang berkembang dalam masyarakat pada waktu tersebut. Berbeda dengan manajemen konvensional, ia merupakan suatu sistem yang aplikasinya bersifat bebas nilai serta hanya berorientasi pada pencapaian manfaat duniawi semata. Manajemen konvensional berusaha unuk diwarnai dengan nilai-nilai, namun dalam perjalanannya tidak mampu, karena ia tidak bersumber dan berdasarkan petunjuk syariah yang bersifat sempurna, komprehensif dan sarat kebenaran. ${ }^{2}$

Selain menekankan pada aspek manajemen, Islam sebagai agama yang sempurna juga sangat menekankan pada adanya mutu dan kualitas dalam segala hal serta perbuatan. Secara khusus, melalui ayat-ayat-Nya Allah Swt menjelaskan proses manajemen, kualitas dan

${ }^{1}$ Didin Hafidhuddin dan Hendri Tanjung, Shariah Principles on Management in Practice (Jakarta: Gema Insani, 2006), h. 1.

${ }^{2}$ Ahmad Ibrahim Abu Sinn, Manajemen Syariah: Sebuah Kajian Historis dan Kontemporer (Jakarta: PT. RajaGrafindo Persada, 2012), h. 28. 
mutu dalam penciptaan dan pengaturan (tadbîr) alam semesta. Perhatian dan perenungan yang mendalam terhadap alam raya bahkan terhadap diri manusia akan mengantarkan pada suatu kesimpulan bahwa Allah Swt Maha Hebat dan Maha Teliti dalam menata dan mengatur jagad raya ini, sebagaimana firman-Nya dalam surat anNaml/27: 88.

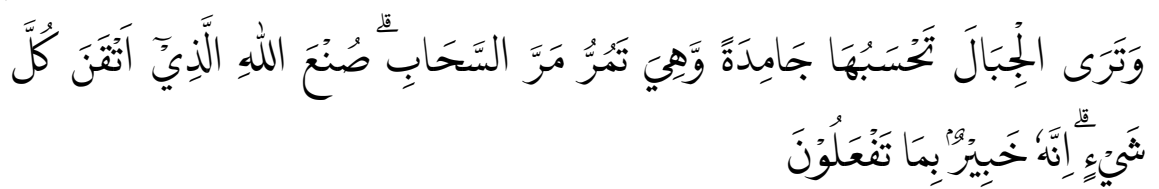

Dan engkau akan melihat gunung-gunung, yang engkau kira tetap di tempatnya, padahal ia berjalan (seperti) awan berjalan. (Itulah) ciptaan Allah yang mencipta dengan sempurna segala sesuatu. Sungguh, Dia Mahateliti apa yang kamu kerjakan. ${ }^{3}$

Ibnu Kasîr menafsirkan bahwa Allah Swt telah menciptakan dengan kokoh setiap ciptaannya dan meletakkan hikmah dalam setiap penciptaan tersebut. ${ }^{4}$ Ini berarti bahwa Allah Swt dalam penciptaan sangat memperhatikan kualitas dan mutu ciptaan-Nya yang tentu tidak terlepas dari ketelitian tingkat tinggi. Dengan demikian Alquran sangat mementingkan dan memperhatikan unsur idâriyah (manajemen) dalam segala sesuatu.

Zakat sebagai suatu kewajiban yang mendasar, memiliki penggunaan tertentu menurut ukuran yang telah diatur oleh syariat. Selain memiliki tujuan ibadah, zakat juga bertujuan untuk merealisasikan fungsi-fungsi sosial, ekonomi dan permodalan dalam masyarakat Islam. ${ }^{5}$ Menunaikan zakat adalah kewajiban sebagai konsekuensi ketaatan kepada perintah Allah swt., dan

${ }^{3}$ Kementerian Agama RI, Alquran dan Terjemahnya (Jakarta: PT. Sinergi Pustaka Indonesia, 2012), h. 542.

4 'Abdullâh bin Muhammad bin 'Abdurraḥmân bin Ishâa al-Sheikh (Ed.), Lubâbut Tafsîr Min Ibni Kasî̀r, Terj. Abdul Ghoffar, E.M dan Abu Ihsan Al-Atsari, Tafsir Ibnu Kasî̂r (Bogor: Pustaka Imam Asy-Syafi'i, 2004), Jil. 6, h. 247.

${ }^{5}$ Syauqî Ismâ‘îl Sahhâtih, at-Tatbîq al-Mu 'âsir li az-Zakah, terj. Bahrun Abu Bakar dan Anshori Umar Sitanggal, Penerapan Zakat dalam Bisnis Modern (Bandung: CV. Pustaka Setia, 2007), h. 77. 
pemanfaatannya dapat membantu menyelesaikan permasalahan ekonomi (mu'âmalah) yang dihadapi oleh masyarakat. Zakat dalam agama Islam tidak sekedar dikumpulkan, melainkan dikelola, dikembangkan dan disalurkan secara kreatif. Dengan demikian lahirlah dua hal sekaligus: kepercayaan dan manfaat. Tanpa kepercayaan, manusia enggan memberikan bagian kekayaannya. Manusia cenderung memilih kepada siapa kekayaan disalurkan. Dan kedua, tanpa manfaat, sebuah organisasi hanya akan menjadi pohon tua yang tak berbuah, karena ia hanya bermanfaat bagi dirinya sendiri. ${ }^{6}$ Oleh karena itu zakat harus dikelola secara profesional melalui manajemen yang bermutu dan berkualitas.

Penelitian yang dilakukan oleh Pusat Kajian Strategis Badan Amil Zakat Nasional (PUSKAS-BAZNAS) dan dipublikasikan pada tahun 2019 menunjukkan bahwa Indeks Pemetaan Potensi Zakat (IPPZ) provinsi Jambi dengan jumlah penduduk Muslim sebanyak 95,41 persen ${ }^{7}$ adalah sebesar 3.047,0 miliar rupiah. ${ }^{8}$ Jika dibandingkan dengan besaran PDRB perkapita provinsi Jambi sebesar Rp. 54.366.370,-, ${ }^{9}$ maka potensi tersebut telah berkontribusi sebesar 2,23 persen ${ }^{10}$ dari total PDRB. Pada tahun 2016 BAZNAS Provinsi Jambi telah menetapkan target atau estimasi penghimpunan dana zakat, infaq dan sedekah (ZIS) untuk seluruh kabupaten/kota se-provinsi Jambi sebesar Rp. 35.325.364.135,81. ${ }^{11}$ Realisasi pengumpulan dana ZIS berdasarkan laporan pada tahun yang sama sebesar Rp.

${ }^{6}$ Rhenald Kasali, “Organisasi Hidup yang Dipercaya dan Bermanfaat,” dalam Eri Sudewo, Manajemen Zakat: Tinggalkan 15 Tradisi Terapkan 4 Prinsip Dasar (Jakarta: Institut Manajemen Zakat, 2004), h. xv-xvi.

${ }^{7}$ Pusat Kajian Strategis-Badan Amil Zakat Nasional dan STEI al-Ishlah Cirebon, Indikator Pemetaan Potensi Zakat (IPPZ) (Jakarta: Pusat Kajian Strategis-Badan Amil Zakat Nasional, 2019), h. 56.

${ }^{8}$ Ibid., h. 119.

${ }^{9}$ Ibid., h. 78.

${ }^{10}$ Ibid., h. 119.

${ }^{11}$ BAZNAS Provinsi Jambi, Profil Badan Amil Zakat Nasional (BAZNAS) Provinsi Jambi Tahun 2016 (Dokumen tidak diterbitkan), h. 26. 
18.424.058.631. ${ }^{12}$ Data ini menggambarkan bahwa target pengumpulan zakat yang ditetapkan oleh BAZNAS Provinsi Jambi masih jauh dari total potensi zakat, infaq dan sedekah yang dimiliki oleh provinsi Jambi secara keseluruhan sebagaimana yang dipaparkan pada data sebelumnya.

Data-data terkait hasil pengelolaan ZIS di atas menunjukkan adanya permasalahan dalam pengelolaan zakat di provinsi Jambi melalui lembaga BAZNAS provinsi maupun kabupaten/kota, sehingga terjadi gap yang signifikan. Permasalahan ini mengakibatkan gagalnya lembaga tersebut dalam mencapai target atau estimasi maksimal penerimaan dana ZIS. Kegagalan ini berakibat pada tidak maksimalnya peranan zakat dalam membantu memecahkan persoalan ekonomi dan mewujudkan kesejahteraan umat sebagaimana yang diharapkan dan sebagaimana peran zakat itu sendiri, yaitu terjadinya transfer pendapatan antara golongan kaya dan golongan miskin. Agar tujuan zakat dapat tercapai maka zakat perlu dikelola secara profesional karena melibatkan dana umat yang peruntukannya sudah ditentukan. ${ }^{13}$

Optimalisasi zakat dipengaruhi oleh kualitas manajemen dan prinsip tata kelola zakat yang baik (good zakat governance), untuk menjamin bahwa dana zakat dari masyarakat telah didayagunakan secara optimal oleh OPZ. ${ }^{14}$ Pengelolaan zakat memerlukan persiapan dan perencanaan yang matang dan terstandar. Semua aktifitas dan faktor-faktor terkait dengan aktifitas tersebut mesti terencana, terorganisir, bahkan terkontrol dan dievaluasi tingkat capaiannya. Hal ini diperlukan agar pengelolaan zakat dapat dilakukan secara efektif dan efisien. Dalam konteks pengelolaan zakat, tujuan zakat akan tercapai manakala zakat dikelola secara baik berdasarkan prinsip-

${ }^{12}$ BAZNAS Provinsi Jambi, Laporan Tahunan Pengelolaan Zakat, Infak dan Sedekah Badan Amil Zakat Nasional (BAZNAS) Provinsi Jambi Tahun 2016 (Dokumen tidak diterbitkan).

${ }^{13}$ Dahlina Dahlan, “Bank Zakat: Pengelolaan Zakat dengan Konsep Bank Sosial Berdasarkan Prinsip Syariah”, dalam Jurnal Ekonomi dan Bisnis Islam, Vol. 4, No. 2, Desember 2018, h. 157.

${ }^{14}$ Nur Kholis, et.al., "Potret Filantrofi Islam di Daerah Istimewa Yogyakarta”, dalam La-Raiba: Jurnal Ekonomi Islam, Vol. 7, No. 1, Juni 2013, h. 68. 
prinsip manajemen. Dengan kata lain, manajemen zakat merupakan perantara bagi tercapainya kesempurnaan pelaksanaan zakat. Oleh karena itu, dalam pengumpulan zakat mestinya didasarkan pada prinsip-prinsip manajemen.

Selain memenuhi standar mutu manajemen pengelolaan, OPZ dalam hal ini BAZNAS sebagai lembaga keuangan yang menghimpun dan menyalurkan dana zakat dari umat Islam, harus berpegang teguh pada prinsip-prinsip dan nilai-nilai syariah Islam. Dengan demikian, manajemen mutu yang diterapkan dalam lembaga tersebut tidak bisa lepas dari kerangka syariah. Kerangka syariah merupakan pilar penting bagi pengembangan berkesinambungan lembaga keuangan Islam. Prinsip-prinsip syariah merupakan penggerak inovasi dan kreativitas, bukan "ketidakleluasaan" yang mencakup berbagai struktur, proses, dan pengaturan tata kelola, yang memastikan bahwa semua operasi dan aktivitas bisnis serta jasa keuangan Islam sesuai dengan syariah. ${ }^{15}$

Kajian ini bertujuan untuk mengkonstruksi atau membangun dan mengembangkan sebuah model manajemen mutu yang berdasarkan pada nilai-nilai syariah untuk diterapkan pada lembaga zakat, khususnya di provinsi Jambi. Kajian ini menggunakan metode kualitatif melalui pendekatan kepustakaan. Data yang digunakan dalam kajian ini merupakan data sekunder dalam bentuk literature dan dokumentasi, yang kemudian dianalisa melalui metode deskriptif. Konstruksi model ini diperlukan dalam rangka membangun, mengembangkan dan memantapkan keberadaan ilmu ekonomi Islam, terutama dalam bidang manajemen melalui penelitian yang terus menerus. Harus diakui bahwa sebagian teori ekonomi syariah (jika dianggap sudah ada) merupakan produk yang diderivasi dari ilmu ekonomi konvensional yang sangat dipengaruhi oleh budaya, serta cara pandang masyarakat Barat. Oleh karena itu perlu dibangun teori ekonomi Islam yang “truly Islamic" yang dibangun dari cara pandang Islam, dan visi Islam. ${ }^{16}$

${ }^{15}$ Asyraf Wajdi Dasuki (Ed.), Sistem Keuangan Islam: Prinsip dan Operasi (Jakarta: PT. RajaGrafindo Persada, 2015), h. 163.

${ }^{16}$ Boedi Abdullah dan Beni Ahmad Saebani, Metode Penelitian Ekonomi Islam (Muamalah) (Bandung: CV. Pustaka Setia, 2014), h. 70. 


\section{B. Kajian Teoritik}

\section{Teori Zakat}

Kata zakat merupakan bentuk mașdar ${ }^{17}$ dari kata zakâ (jك) yang berarti berkah, tumbuh, bersih, dan baik. Dalam istilah fiqih, zakat adalah sebutan atau nama bagi sejumlah harta tertentu yang diwajibkan Allah Swt supaya diserahkan kepada orang-orang yang berhak (mustahik). ${ }^{18}$ Zakat dalam definisi para fuqaha menurut Wahbah az-Zuhailî dalam kitab al-Fiqhul-Islâmî wa Adillatuhu adalah memberikan hak yang wajib pada harta. Zakat dalam 'urf fuqaha digunakan juga untuk pengertian bagian tertentu dari harta yang telah ditetapkan oleh Allah sebagai hak orang orang fakir. Zakat dinamakan șadaqah karena menunjukkan kejujuran hamba dalam beribadah dan taat kepada Allah Swt. ${ }^{19}$ Zamakhsyarî dalam kitab al-Fâ'iq, sebagaimana dikutip oleh Dr. Yusuf Qardawi dalam karyanya Fiqh azZakâh, mendefinisikan zakat dari segi istilah fiqih sebagai sejumlah harta tertentu yang diwajibkan Allah Swt diserahkan kepada orangorang yang berhak. ${ }^{20}$

Berdasarkan beberapa definisi diatas, hampir tidak ada perbedaan arti atau definisi zakat di kalangan para ulama maupun para ahli bahasa, baik secara etimologi maupun secara terminologi fiqh. Bahkan satu definisi dengan definisi lainnya saling melengkapi. Dengan demikian, definisi zakat dalam penelitian ini adalah sejumlah harta yang wajib dikeluarkan sebagai sebuah kewajiban, untuk golongan tertentu dengan syarat-syarat yang telah diatur oleh syariat Islam guna mensucikan harta dan pemiliknya.

${ }^{17}$ Mașdar dalam istilah ketatabahasaan (Arab) berarti bentuk kata kerja infinitif. Lihat: Departemen Pendidikan Nasional, Kamus Bahasa Indonesia (Jakarta: Pusat Bahasa, 2008), h. 922.

${ }^{18}$ Dewan Redaksi Ensiklopedia Islam, Ensiklopedia Islam (Jakarta: PT. Ichtiar Baru Van Hoeve, 2003), Jilid V, h. 224.

${ }^{19}$ Wahbah az-Zuhailî, al-Fiqhul-Islâmî wa Adillatuhu, Terj. Fiqih Islâm wa Adillatuhu (Jakarta: Gema Insani Press, t.t), Jilid III, h. 166.

${ }^{20}$ Yûsuf Qaraḍawî, Fiqh az-Zakâh, terj. Salman Harun, dkk, Hukum Zakat (Bogor: Pustaka Litera AntarNusa, 2011), h. 34. 
Dalam Alquran, kata-kata zakat diungkapkan dalam beberapa istilah, di antaranya adalah zakat $^{21}$, șadaqah ${ }^{22}$, nafaqah ${ }^{23}, h a q^{24}$ dan 'af $w^{25}$. Keseluruhan istilah tersebut merujuk pada satu makna yaitu zakat. ${ }^{26}$ Namun demikian terdapat perbedaan dalam beberapa aspek, seperti aspek kewajiban, syarat-syarat penunaian dan pihak-pihak penerimanya. Khusus kata sedekah disebutkan sebanyak lima kali dalam Alquran dengan makna zakat wajib, ${ }^{27}$ sehingga al-Mawardi ${ }^{28}$ mengatakan bahwa "sedekah itu adalah zakat dan zakat itu adalah sedekah; berbeda nama tetapi arti sama.” 29

\section{Teori Pengelolaan Zakat}

Adanya kewajiban dan peraturan yang jelas terkait zakat, menyebabkan penerimaan zakat lebih banyak dan diharuskan adanya sistem pengelolaan yang lebih terstruktur. Oleh karena itu, Rasulullah saw membuat tempat pengumpulan dan pengelolaan distribusi zakat yang bernama Baitul Mâl (rumah harta), yang saat itu terletak di masjid Nabawi. Pada saat itu, Rasulullah saw juga mengutus para sahabatnya untuk menjadi amil (pengelola zakat) di daerah jazirah Arab termasuk di dalamnya kota Yaman, seperti: 'Umar bin Khațtâb, Ibnu Qaiz 'Ubaidah bin Samit dan Mu'âz bin Jabal. ${ }^{30}$

Sedangkan pada masa khulafâurrâsyidîn dan dinasti-dinasti Islam selanjutnya, tugas tersebut secara otomatis beralih kepada para

${ }^{21}$ Q.S. al-Baqarah/2: 110.

${ }^{22}$ Q.S. at-Taubah/9: 60 .

${ }^{23}$ Q.S. at-Taubah/9: 34.

${ }^{24}$ Q.S. al-An'âm/6: 114.

${ }^{25}$ Q.S. al-A'râf/7: 199.

${ }^{26}$ Budi Trianto, "Model Pemberdayaan Masyarakat Miskin Perkotaan oleh Institusi Zakat di Pekan Baru” (Disertasi, Pascasarjana Universitas Islam Negeri Sumatera Utara Medan, 2019), h. 25.

${ }^{27}$ Monzer Kahf, an-Nusûș al-Iqtișâdiyyah min al-Qurân wa as-Sunnah (Jeddah: Markaz an-Nasyr al-'ilmi, t.t), h. 685.

${ }^{28}$ al-Mawardi adalah seorang ahli hukum dari mazhab Syafi'i, wafat tahun 450 H/1058 M di Bagdad, beliau penulis Kitâb al-Ahkâm as-Sulțâniyyah (Buku Hukum Tata Negara). Lihat: Dewan Redaksi Ensiklopedia Islam, Ensiklopedia, Jilid I, h. 73

${ }^{29}$ Qaraḍawî, Fiqh, h. 36.

${ }^{30}$ BI dan P3EI FE-UII, Pengelolaan, h. 69. 
khalifah atau penguasa. Oleh karena itu, tidak mengherankan jika pada masa Abû Bakr menjabat sebagai khalifah, beliau membuat kebijakan memerangi para pembangkang zakat. Bahkan para pengingkar zakat tersebut dinyatakan telah keluar dari Islam (kafir), sedangkan orang-orang yang menahan zakat karena sifat bakhilnya, maka hartanya diambil secara paksa dan pemilik harta tersebut diasingkan (ta zîr). ${ }^{31}$ Hal ini merupakan kelanjutan dari apa yang telah dicontohkan oleh Rasulullah saw sebelumnya, yang sangat besar perhatiannya terhadap masalah zakat.

Berdasarkan uraian sejarah pengelolaan dan pemberdayaan zakat di atas, maka dapat disimpulkan bahwa secara teori zakat dikelola oleh pemerintah atau negara melalui lembaga khusus, dan didistribusikan kepada yang berhak untuk menerimanya, yakni berdasarkan 8 (delapan) golongan penerima zakat, baik melalui prinsip kesamarataan maupun keutamaan. Abû 'Ubaid al-Qâsim menegaskan dalam karyanya Kitâb al-Amwâl bahwa harta-harta yang manjadi tanggung jawab pemimpin untuk dikelola dengan baik terbagi kepada tiga, sebagaimana juga pendapat 'Umar bin Khațâab, yaitu fa'i, khumus $^{32}$ dan zakat. ${ }^{33}$

Berdasarkan teori social of engineering yang dipelopori oleh pemikiran Roscoe Pound menyebutkan bahwa hukum, dalam hal ini undang-undang merupakan alat untuk rekayasa sosial. Mochtar Kusumaatmaja mengartikan bahwa hukum (UU) sebagai sarana/alat pembaharuan masyarakat yang mencerminkan nilai-nilai dalam masyarakat tersebut. Dalam pengelolaan zakat diperlukan peran negara yang lebih besar dalam pengelolaan zakat agar menjadi

31 'Abdullâh al-Muṣlih dan Șalâh as-Sawî, Mâ la Yasa'u al-Muslim Jahluhu (arRiyâd: Dar Isybiliya, cet. 1, 1419 H/1998 M), h. 209.

${ }^{32} \mathrm{Fa}$ 'i adalah harta yang dipungut dari ahli żimmah sesuai dengan perjanjian perdamian bersama mereka, yaitu sebagai pajak kepala yang telah dijamin keselamatan jiwa dan hartanya. Harta ini merupakan hak umum umat Islam yang dijadikan sumber gaji para tentara dan gaji anak pejuang. Sedangkan khumus adalah seperlima harta ganîmah kafir harbi, rikâz, barang tambang dan ma'dân. Lihat: Abû 'Ubaid al-Qâsim, Kitâb al-Amwâl, Terj. Setiawan Budi Utomo, Ensiklopedia Keuangan Publik: Zakat, Pajak (Depok: Gema Insani, 2006), h. 78.

${ }^{33}$ Abû 'Ubaid al-Qâsim, Kitâb al-Amwâl, Terj. Setiawan Budi Utomo, Ensiklopedia Keuangan Publik: Zakat, Pajak (Depok: Gema Insani, 2006), h. 77. 
aplikatif dan tercapainya tujuan negara, yaitu kesejahteraan da penanggulangan kemiskinan. Negara tidak sekedar memberikan regulasi (hukum-UU), namun juga harus hadir dalam peran yang lebih konkrit dalam pengelolaan zakat sebagai motivator, fasilitator dan pelopor. ${ }^{34}$

Merujuk kepada UU Nomor 23 Tahun 2011, zakat di Indonesia dikelola langsung oleh negara yang berasaskan syariat Islam, amanah, kemanfaatan, keadilan, kepastian hukum, terintegrasi dan akuntabilitas. Sedangkan tujuan pengelolaan zakat adalah efektivitas dan efisiensi pengelolaan zakat, serta manfaat zakat untuk kesejahteraan dan penanggulangan kemiskinan. ${ }^{35}$

\section{Teori Tata Kelola Syariah pada Lembaga Pengelola Zakat}

Berdasarkan sifat dan karakteristik organisasi, maka lembaga pengelola zakat merupakan organisasi nirlaba, karena tidak berorientasi untuk mengumpulkan keuntungan dari kegiatan operasionalnya. Jika dilihat dari kegiatan yang dilakukan oleh lembaga pengelola zakat, maka dapat dikategorikan sebagai lembaga keuangan. Definisi umum yang dimaksud dengan lembaga keuangan menurut undang-undang adalah semua badan yang melalui kegiatankegiatannya di bidang keuangan menaruh uang dari dan menyalurkannya ke dalam masyarakat. ${ }^{36}$

Islam secara kuat menganjurkan semua bentuk tata kelola yang positif, dan selama ini, nilai-nilai ini sudah dibangun dan inheren di dalam masyarakat. Tata kelola lembaga keuangan Islam berfungsi melalui prinsip-prinsip pokok Islam tentang kesejahteraan ekonomi, persaudaraan universal, keadilan, akuntabilitas, dan distribusi pemasukan yang setimpal. Keutamaan Islam selalu menganjurkan tata

34 Sri Kusriyah, "Politik Hukum Pengelolaan Zakat Sebagai Instrumen Penanggulangan Kemiskinan: Studi Kebijakan Pengelolaan Zakat di Provinsi Jawa Tengah" (Disertasi, Program Pascasarjana Fakultas Hukum Universitas Islam Indonesia Yogyakarta, 2015), h. 445.

35 Undang-Undang Republik Indonesia Nomor 23 Tahun 2011 tentang Pengelolaan Zakat (Lembaran Negara Republik Indonesia Tahun 2011 Nomor 115).

${ }^{36}$ Undang-Undang Republik Indonesia Nomor 14 Tahun 1967 Tentang PokokPokok Perbankan (Lembaran Negara Republik Indonesia Nomor 2842 Tahun 1967). 
kelola lembaga yang tepat dan, berdasarkan ini, lembaga-lembaga keuangan Islam harus mengabungkan tata kelola lembaga yang tepat ke dalam semua aspek operasionalnya, ${ }^{37}$ seperti halnya lembaga pengelola zakat.

Definisi tata kelola dalam konteks lembaga keuangan Islam dapat ditemukan dalam Guiding Principles on Corporate Governance for Institutions Offering only Financial Services (Excluding Islamic Insurance [Takaful] Institutions and Islamic Mutual Funds) yang diterbitkan oleh Islamic Financial Services Board (IFSB) sebagai berikut:

"Seperangkat pengaturan organisasi yang melaluinya tindakantindakan pihak manajemen di lembaga yang menawarkan jasajasa keuangan Islam diselaraskan, sejauh mungkin, dengan kepentingan para pemangku kepentingan lembaga tersebut; penyediaan insentif-insentif tepat bagi organisasi-organisasi tata kelola, seperti dewan direksi, Dewan Pengawas Syariah (DPS), dan pihak manajemen, agar mereka mengejar sasaransasaran yang perlu dicapai demi kepentingan para pemangku kepentingan, serta memfasilitasi pengawasan yang efektif, menggunakan sumber daya dengan lebih efisien, serta mematuhi kaidah-kaidah dan prinsip-prinsip syariah Islam". ${ }^{38}$

Desain tata kelola lembaga keuangan Islam mempunyai fiturfitur unik tersendiri dan menampilkan karakteristik yang khas bila dibandingkan dengan konsep-konsep lain dalam beberapa aspek, yaitu pengetahuan (episteme), sasaran, dan sifat serta jajaran manajemen. Berikut ini ikhtisar komparatif tata kelola lembaga keuangan dari perspektif:

${ }^{37}$ International Shari'ah Research Academic for Islamic Finance (ISRA), Sistem Keuangan Islam: Prinsip dan Operasi, ed. Asyraf Wajdi Dusuki (Jakarta: Rajawali Pers, 2015), h. 160-161.

${ }^{38}$ Ibid., h. 820. 
Tabel: Ikhtisar Desain Tata Kelola Lembaga Keuangan ${ }^{39}$

\begin{tabular}{|c|c|c|c|}
\hline Aspek & $\begin{array}{l}\text { Model Anglo- } \\
\text { Saxon }\end{array}$ & Model Eropa & Model Islam \\
\hline Pengetahuan & $\begin{array}{l}\text { Rasionalisme } \\
\text { dan rasionalitas }\end{array}$ & $\begin{array}{l}\text { Rasionalisme } \\
\text { dan rasionalitas }\end{array}$ & Tauhid \\
\hline \multicolumn{4}{|l|}{ Sasaran } \\
\hline $\begin{array}{l}\text { Hak-hak dan } \\
\text { kepentingan }\end{array}$ & $\begin{array}{l}\text { Melindungi } \\
\text { kepentingan } \\
\text { dan hak-hak } \\
\text { para pemegang } \\
\text { saham }\end{array}$ & $\begin{array}{l}\text { Hak masyarakat } \\
\text { dalam } \\
\text { kaitannya } \\
\text { dengan } \\
\text { lembaga }\end{array}$ & $\begin{array}{l}\text { Melindungi } \\
\text { kepentingan } \\
\text { dan hak-hak } \\
\text { semua } \\
\text { pemangku } \\
\text { kepentingan, } \\
\text { tetapi tunduk } \\
\text { pada kaidah- } \\
\text { kaidah syariah }\end{array}$ \\
\hline $\begin{array}{l}\text { Tujuan } \\
\text { lembaga }\end{array}$ & $\begin{array}{l}\text { Para pemegang } \\
\text { saham } \\
\text { mengontrol } \\
\text { para manajer } \\
\text { karena alas an } \\
\text { menghasilkan } \\
\text { laba bagi para } \\
\text { pemegang } \\
\text { saham }\end{array}$ & $\begin{array}{l}\text { Masyarakat } \\
\text { mengontrol } \\
\text { lembaga } \\
\text { tersebut karena } \\
\text { alasan } \\
\text { meningkatkan } \\
\text { kesejateraan } \\
\text { sosial }\end{array}$ & $\begin{array}{ll}\text { Sasaran } & \\
\text { syariah } & \text { atau } \\
\text { maqâșid } & \text { asy- } \\
\text { syarî'ah } & \end{array}$ \\
\hline $\begin{array}{l}\text { Sifat pihak } \\
\text { manajemen }\end{array}$ & $\begin{array}{l}\text { Dominasi pihak } \\
\text { manajemen }\end{array}$ & $\begin{array}{l}\text { Dominasi } \\
\text { pemegang } \\
\text { saham } \\
\text { pengontrol }\end{array}$ & $\begin{array}{l}\text { Konsep } \\
\text { perwakilan, } \\
\text { syura, serta } \\
\text { proses yang } \\
\text { interaktif, } \\
\text { terintegrasi } \\
\text { dan } \\
\text { evolusioner }\end{array}$ \\
\hline Jajaran & Jajaran & Jajaran & Badan \\
\hline
\end{tabular}

${ }^{39}$ Ibid., h. 827. 
Konstruksi Model Manajemen...

\begin{tabular}{|l|l|l|l|}
\hline manajemen & tingkat & $\begin{array}{l}\text { tingkat: } \\
\text { eksekutif dan } \\
\text { pengawas } \\
\text { memegang } \\
\text { tanggungjawab } \\
\text { terpisah }\end{array}$ & $\begin{array}{l}\text { Pengawas } \\
\text { Syariah } \\
\text { sebagai tata } \\
\text { kelola pokok }\end{array}$ \\
\hline $\begin{array}{l}\text { Modal dan } \\
\text { struktur } \\
\text { kepemilikan }\end{array}$ & $\begin{array}{l}\text { Kepemilikan } \\
\text { yang sangat } \\
\text { terpencar, } \\
\text { dividen-dividen } \\
\text { diprioritaskan }\end{array}$ & $\begin{array}{l}\text { Bank-bank dan } \\
\text { perusahaan } \\
\text { lainnya } \\
\text { merupakan } \\
\text { para pemegang } \\
\text { saham utama; } \\
\text { dividen-dividen } \\
\text { lebih tidak } \\
\text { diprioritaskan }\end{array}$ & $\begin{array}{l}\text { Para } \\
\text { pemegang } \\
\text { saham dan dan deposan } \\
\text { para dangang } \\
\text { rekening } \\
\text { investasi }\end{array}$ \\
\hline
\end{tabular}

Sebagai lembaga keuangan non-profit dan nirlaba, lembaga zakat memerlukan tata kelola yang berdasarkan pada nilai-nilai syariah untuk memberikan arah standar operasi yang terukur, sehingga mencapai sasaran dan tujuan dengan efektif dan efisien. Dalam hal ini, perlu dirumuskan suprastruktur pengelolaan zakat, baik yang berasal dari aturan fikih, undang-undang, maupun konsep tata kelola dan manajemen yang baik. Dengan diterapkannya tata kelola syariah, maka pengelolaan zakat akan mencapai tujuan dan prinsipprinsip disyariatkannya zakat oleh Allah Swt (maqâșid asy-syarî'ah). ${ }^{40}$ Adapun prinsip-prinsip syariat yang dimaksud dalam kewajiban zakat adalah mewujudkan keadilan distributif, memelihara aqidah (hifz ad-

${ }^{40}$ Istilah maqâsid asy-syarî‘ah memiliki makna sebagai apa yang dimaksud, dituju atau yang ingin dicapai oleh Allah Swt dalam menetapkan suatu hukum. Lihat: Muhammad Zaki dan Bayu Tri Cahya, "Aplikasi Maqâsid asy-Syarî́ah Pada Sistem Keuangan Syariah”, dalam Jurnal Bisnis dan Manajemen Islam, Vol. 3, Desember 2015, h. 314. Dalam kajian ilmu Ușûl Fiqh, maqâsid asy-syarî‘ah mengandung arti yang sama dengan kata al-hikmah, yaitu tujuan yang dimaksud Allah Swt. dalam penetapan suatu hukum. Lihat: Amir Syarifuddin, Ushul Fiqh (Jakarta: Prenada, 2008) cet. IV, Jilid. 2, h. 231. 
dîn) para muzakki dan mustahik, memelihara harta (hifz al-mâl), memelihara keturunan (hifz an-nasl), dan memelihara akal (hifz al'aql). ${ }^{41}$

\section{Teori Manajemen Mutu dalam Perspektif Syariah}

Pada masa awal perkembangan Islam, manajemen dianggap sebagai ilmu sekaligus teknik (seni) dalam kepemimpinan, dan belum ada definisi baku terkait apa yang disebut dengan manajemen Islami. ${ }^{42}$ Pendapat lain menyebutkan bahwa kristalisasi pemikiran manajemen dalam Islam muncul setelah Allah Swt menurunkan risalah-Nya kepada nabi Muhammad saw. ${ }^{43}$ Istilah manajemen dalam bahasa Arab disebut dengan istilah al-idârah (الإدارة) Alquran dan tidak pula dalam hadis Rasulullah saw. Hal ini menunjukkan bahwa penggunaan istilah al-idârah dalam Islam merupakan sesuatu yang baru. ${ }^{45}$ Manajemen dalam perspektif Islam

${ }^{41}$ Oneng Nurul Bariyah, “Prinsip-Prinsip Syariah dalam Pengelolaan Zakat oleh Lembaga Pegelola Zakat”, dalam Madania: Jurnal Kajian Keislaman, Vol. 17, No. 2, Desember 2013, h. 12.

${ }^{42}$ Abdul Halim Usman, Manajemen Strategis Syariah (Jakarta: Zikrul Hakim, 2015), h. 48 .

${ }^{43}$ Sinn, Manajemen, h. 28.

${ }^{44}$ Ahmad Warson Munawwir, Kamus Arab-Indonesia Terlengkap (Surabaya: Pustaka Progressif, 1997), h. 678. Dalam kamus ini, kata الإدار sepadan dengan kata السياسة yang berarti administrasi. Kedua istilah tersebut (manajemen dan administrasi) dibedakan berdasarkan zona penggunaannya. Istilah manajemen lebih banyak digunakan pada literatur pemikir bangsa Inggris, sedangkan adminstrasi dipakai dalam literatur pemikir bangsa Amerika. Di Indonesia kedua istilah dalam kedudukannya bisa diartikan sama sejajar, administrasi lebih tinggi/luas dari manajemen, dan ada juga yang memposisikan administrasi di bawah manajemen. Memposisikan administrasi sebagai bagian dari manajemen merujuk pada pemahaman bahwa administrasi sebagai suatu pekerjaan tata tulis (clerical work). Sedangkan orang yang mensejajarkan istilah tersebut merujuk pada pemahaman bahwa kedua-duanya merupakan suatu usaha penataan kelembagaan mulai dari perencanaan kegiatan, melaksanakan, mengawasi, mengevaluasi, dan melaporkan secara bertanggung jawab. Lihat: Engkoswara dan Aan Komariah, Administrasi Pendidikan (Bandung: Alfabeta, 2011), h. 85.

${ }^{45}$ Hâfiz Ahmad 'Ujâj al-Karmî, al-Idârah fî 'asri ar-Rasûl: Dirâsah Târîkhiyyah li an-Nuzum al-Idâriyyah fî ad-Daulah al-Islâmiyyah al-Ûlâ (al-Qâhirah: Dârussalâm, 2006), h. 27. 
atau syariah dapat diartikan sebagai akivitas perencanaan, pengorganisasian, pengarahan, dan pengawasan yang dilakukan oleh seorang manajer kepada orang-orang yang berada dalam kepemimpinannya guna mencapai tujuan yang ditetapkan, serta dilaksanakan dengan sungguh-sungguh berlandaskan pada nilai-nilai syariah.

Adapun istilah mutu (quality/kualitas) dalam bahasa Arab sepadan dengan istilah jawdah (جودة), yang berasal dari ja-wa-da (ج) و، (ج) yang berarti memberikan hasil yang terbaik atau sempurna, baik dalam perkataan maupun perbuatan, sehingga terwujud kepuasan konsumen. ${ }^{46}$ Istilah jawdah, kata ihsân (إحسان) dan itqân (إتقان) dalam bahasa Arab juga memiliki arti yang serupa dengan mutu (quality/kualitas). ${ }^{47}$

Manajemen mutu adalah sebuah filosofi tentang perbaikan secara terus-menerus, yang dapat memberikan seperangkat alat praktis kepada setiap institusi dalam memenuhi kebutuhan, keinginan, dan harapan para pelanggan, saat ini dan untuk masa yang akan datang, ${ }^{48}$ serta merupakan sebuah pola pikir sekaligus aktivitas praktis. ${ }^{49}$ Definisi lain dari manajemen mutu adalah sistem pengendalian mutu yang didasarkan pada filosofi bahwa memenuhi kebutuhan pelanggan dengan sebaik-baiknya adalah yang utama dalam setiap usaha. ${ }^{50}$ Adapun manajemen mutu syariah dalam

46 ‘Âdil ibn ‘Âyid asy-Syamrî, “al-Jawdah asy-Syâmilah baina al-Manzûr al-Islâmî wa ar-Ru'yah al-Garbiyyah”, dalam al-Majallah al- 'Arabiyyah li D\}imâni Jawdatitta'lîm alJâmi 'î, Vol. 19, 2015, h. 52. Makna yang sama juga dapat ditemukan dalam: Majduddîn Muhammad ibn Ya'qûb al-Fairuzzabâdî, al-Qâmûs al-Muhît (al-Qâhirah: Dâr al-Hadîs, 2008), h. 308 dan dalam: Ahmad Mukhtâr 'Umar, Mu'jam al-Lugah al-'Arabiyyah alMu'âsirah (al-Qâhirah: 'Âlamul Kutub, Jilid I, 2008), h. 417.

${ }^{47}$ Ahamad Faosiy Ogunbado dan Asia Mus'ab al-Otaibi, “Is Quality Management an Islamic Value?”, dalam IOSR Journal of Business and Management, Vol. 8, Issue 3, MarApr 2013, h. 7.

${ }^{48}$ Edward Sallis, Manajemen Mutu Terpadu Pendidikan, terj. Ahmad Ali Riyadi dan Fahrurrozi (Jakarta: IRCiSoD, 2010), h. 73.

${ }^{49}$ Ibid., h. 76.

${ }^{50}$ Vithzal Rivai Zaenal, et.al., Islamic Management: Meraih Sukses Melalui Praktis Manajemen Gaya Rasulullah Secara Istiqomah (Yogyakarta: BPFE, 2013), h. 254. 
penelitian ini adalah seperangkat sistem pengendalian mutu lembaga yang didasarkan pada nilai-nilai Islam (syariah).

\section{Hasil Penelitian dan Pembahasan}

\section{Gambaran Umum BAZNAS Provinsi Jambi ${ }^{51}$}

Badan Amil Zakat Nasional (BAZNAS) Provinsi Jambi merupakan badan resmi yang dibentuk oleh pemerintah berdasarkan Keputusan Presiden RI No.8 Tahun 2001 yang memiliki tugas dan fungsi menghimpun dan menyalurkan zakat, infaq dan sedekah (ZIS) pada tingkat Provinsi Jambi, Kabupaten dan Kota. Lahirnya Undang-Undang Nomor 23 tahun 2011 tentang Pengelolaan Zakat semakin mengukuhkan peran BAZNAS sebagai lembaga yang berwenang melakukan pengelolaan zakat. Dalam Undang-Undang tersebut, BAZNAS dinyatakan sebagai lembaga pemerintah non-struktural yang bersifat mandiri dan bertanggung jawab kepada Gubernur dan Kakanwil Kementerian Agama Provinsi Jambi. Dengan demikian, BAZNAS bersama Pemerintah bertanggung jawab untuk mengawal pengelolaan zakat yang berasaskan; syariat Islam, amanah, kemanfaatan, keadilan, kepastian hukum, terintegrasi dan akuntabilitas.

Dalam menjalankan tugas yang amanah, maka BAZNAS mempunyai empat fungsi, yaitu:

a. Perencanaan pengumpulan, pendistribusian, dan pendayagunaan zakat

b. Pelaksanaan pengumpulan, pendistribusian, dan pendayagunaan zakat

c. Pengendalian pengumpulan, pendistribusian, dan pendayagunaan zakat

d. Pelaporan dan pertanggungjawaban pelaksanaan pengelola zakat.

Untuk terlaksananya tugas dan fungsi tersebut, maka BAZNAS Provinsi Jambi memiliki kewenangan:

a. Menghimpun, mendistribusikan, dan mendayagunakan zakat

${ }^{51}$ BAZNAS Provinsi Jambi, Profil Badan Amil Zakat Nasional (BAZNAS) Provinsi Jambi Tahun 2016 (Dokumen tidak diterbitkan) 
b. Memberikan rekomendasi dalam pembentukan, BAZNAS Kabupaten/Kota, dan LAZ

c. Meminta laporan pelaksanaan pengelolaan zakat, infak, sedekah, dan dana sosial keagamaan lainnya kepada BAZNAS Kabupaten/Kota dan LAZ, untuk diteruskan kepada BAZNAS Nasional.

Berbagai prestasi yang diberikan oleh BAZNAS pusat berdasarkan Undang-Undang Nomor 23 tahun 2011 terutama dengan struktur yang baik, bahwa BAZNAS Provinsi Jambi telah berhasil:

a. Membentuk kepengurusan yang baru baik dari tingkat provinsi maupun BAZNAS Kabupaten/Kota dalam Provinsi Jambi.

b. Tahun 2016 BAZNAS Provinsi Jambi telah berhasil melakukan entri data secara nasional (tanggal 3-5 Oktober 2016) terbaik melalui Simda baik data dari BAZNAS Provinsi Jambi maupun Kabupaten/Kota.

c. Kecepatan dan keakuratan data yang disampaikan ke BAZNAS pusat tergolong lancar dan bisa dipertanggung jawabkan.

d. Peningkatan penerimaan dan kecepatan pendistribusian berjalan dengan baik yang tergabung untuk mensukseskan Jambi Cerdas, Jambi Makmur, Jambi Taqwa dan Jambi Sejahtera menuju Jambi Tuntas (Tertib, Unggul, Nyaman, Tangguh, Aman dan Sejahtera) tahun 2021 sesuai dengan visi, misi gubernur Jambi.

Visi, Misi dan Motto BAZNAS Provinsi Jambi:

a. Visi

Menjadikan BAZNAS Provinsi Jambi sebagai organisasi pengelola zakat, infaq dan sedekah yang amanah, adil, berdedikasi, profesional, transparan dan mandiri.

b. Misi

1) Meningkatkan kesadaran umat dalam menunaikan zakat melalui BAZNAS Provinsi Jambi dalam rangka pengamalan keimanan dan ketaqwaan kepada Allah Swt.

2) Mengoptimalkan pengumpulan dan pendayagunaan zakat untuk mewujudkan masyarakat sejahtera lahir dan batin yang di ridhoi Allah Swt. 
3) Mewujudkan BAZNAS Provinsi Jambi sebagai lembaga pengelola zakat, infaq dan sedekah yang amanah.

c. Motto: Satu tekad, bayar zakat, kita selamat

Berdasarkan keputusan ketua BAZNAS Provinsi Jambi No. 09/Baznas-I/I/2016 tanggal 14 Januari 2016 tentang program kerja Baznas Provinsi Jambi dapat disimpulkan sebagai berikut:

a. Peningkatan pengumpulan dana zakat, infaq, sedekah dan dana sosial keagamaan lainnya (baik dalam bentuk CSR, dana hibah dari APBN/APBD).

b. Pelayanan terhadap muzakki.

c. Pendataan Muzakki dan mustahiq.

d. Pemberian kebutuhan hidup yang mendasar, seperti sandang, pangan dan papan (Jambi Sejahtera).

e. Pemberian bantuan biaya pendidikan (Jambi Cerdas).

f. Pemberian bantuan kesehatan (Jambi Sehat).

g. Peningkatan kegiatan dakwah (Jambi Taqwa).

h. Pemberian bantuan untuk yang terlantar (Jambi Peduli).

i. Peningkatan kapabilitas dan professionalitas UPZ dan amilin BAZNAS.

BAZNAS Provinsi Jambi sebagai badan pengelola zakat tingkat provinsi berupaya melakukan kebijakan mutu sebagai berikut:

a. Pembinaan, pengembangan dan penyadaran kewajiban berzakat demi meningkatkan kesejahteraan serta kualitas kehidupan masyarakat.

b. Memberikan pelayanan yang terbaik bagi muzakki dan mustahiq.

c. Membuat program pemberdayaan yang terencana dan berkesinambungan dalam meningkatkan taraf hidup mustahiq dan muzakki.

d. Menyajikan data penerimaan dan pendayagunaan zakat yang akurat karena didukung oleh amil yang berkerja secara professional.

e. Manajemen yang fokus terhadap pembinaan dan pengembangan sumber daya manusia sebagai amil yang menjalankan amanah.

f. Selalu mengedepankan keselamtan dan kesehatan kerja bagi seluruh amil untuk keberhasilan dan kesuksesan penerapan hal-hal 
diatas menjadi tanggung jawab pimpinan dan seluruh Amil BAZNAS Provinsi Jambi.

Tujuan kebijakan mutu tersebut adalah:

a. Menjadikan program unggulan BAZNAS Provinsi Jambi sebagai mainstream (arus utama) program pendayagunaan Organisasi Pengelola Zakat (OPZ) khususnya di Provinsi Jambi.

b. Memaksimalkan partisipasi organisasi pengelola zakat dalam mendukung program bersama pendayagunaan zakat di Provinsi Jambi.

c. Fokus kepada instansi pemerintah, BUMN/BUMD melalui penguatan regulasi.

d. Mendorong dan mengupayakan diterbitkannya peraturan daerah bagi penguatan regulasi yang sudah ada, baik instruksi Gubernur nomor 01 tahun 2011, maupun edaran Gubernur Jambi tahun 2015.

e. Penguatan sentralisasi data di daerah baik muzakki maupun jumlah penghimpunan.

f. Melakukan sosialisasi bersama.

g. Optimalkan KKI (Koordinasi, Konsultasi, Informai) melalui penyusunan mekanisme dan sistem koordinasi, penguatan lembaga serta SDM OPZ dan UPZ.

h. Meningkatkan kerjasama antar lembaga yang telah ada untuk meningkatkan pemasukan dan pendistribusian dana ZIS.

i. Intesifikasi dan ekstensifikasi hubungan kemitraan dan koordinasi dengan instansi pemerintah, BUMN/BUMD, perbankan syariah, dan organisasi sosial/keagamaan di Jambi.

j. Penyempurnaan regulasi dan SOP dan tupoksi.

k. Peningkatan sumber dana dan sumber daya.

1. Reorganisasi dan konsolidasi organisasi.

BAZNAS Provinsi Jambi disamping berkoordinasi dengan BAZNAS pusat juga selalu bekerjasama dengan BAZNAS kabupaten/kota dalam Provinsi Jambi terutama dalam meningkatkan pola kemitraan dan kerja bareng baik bidang target pengumpulan yang telah ditetapkan oleh BAZNAS pusat maupun pola pendistribusian agar tepat sasaran di daerah. Salah satu dari koordinasi dimaksud di 11 
daerah tingkat II telah difasilitasi dan terbentuk kepengurusan yang baru dan telah sesuai dengan ketentuan dan peraturan terbaru sekaligus sebagai link ke daerah yaitu:

a. Baznas Kota Jambi.

b. Baznas Kabupaten Muaro Jambi di Sengeti.

c. Baznas Kabupaten Tanjung Jabung Barat di Kuala Tungkal.

d. Baznas Kabupaten Tanjung Jabung Timur di Muara Sabak.

e. Baznas Kabupaten Batanghari di Muara Bulian.

f. Baznas Kabupaten Tebo di Muaro Tebo.

g. Baznas Kabupaten Bungo di Muara Bungo.

h. Baznas Kabupaten Sarolangun.

i. Baznas Kabupaten Merangin.

j. Baznas Kabupaten Kerinci.

k. Baznas Kabupaten Sungai Penuh.

\section{Konstruksi Manajemen Mutu Syariah dalam Pengelolaan Zakat di BAZNAS Provinsi Jambi}

Manajemen mutu lembaga pengelola zakat merupakan diskursus yang relatif baru, hingga kini, belum ada model manajemen BAZNAS yang diterima secara universal, karena berbagai alasan. Dalam Islam, konsep manajemen lembaga merujuk kepada seperangkat pengaturan organisasi perihal cara suatu lembaga diarahkan, diatur, dikendalikan, dan diawasi. Desain model tata kelola lembaga mempunyai fitur-fitur unik tersendiri dan menampilkan karakteristik yang khas, bila dibandingkan dengan dengan konsep-konsep Barat seperti model Anglo-Saxon dan model Eropa. Secara keseluruhan, dalam Islam, basis model manajemen lembaga BAZNAS merujuk pada epistemologi tauhid serta kaidah-kaidah dan prinsip-prinsip manajemen secara umum, seperti perencanaan, pengorganisasian, pengarahan, dan pengawasan yang dilandaskan pada nilai-nilai syariah serta berorientasi kepada seluruh pemangku kepentingan.

Tauhid merujuk pada pengakuan tentang hak-hak unik Allah Swt dan tanggung jawab semua pemangku kepentingan di hadapan Allah Swt. Manajemen mutu syariah pengelolaan BAZNAS terikat dengan kaidah-kaidah dan prinsip-prinsip syariah berasaskan pada nilai-nilai kemanusiaan yang berkembang dalam masyarakat di provinsi Jambi. 
Selain itu, aksioma-aksioma dasar dalam manajemen Islam yang dirumuskan berdasarkan Alquran dan sunnah, juga menyediakan fondasi filosofis tata kelola lembaga BAZNAS dengan model Islami. Dalam konteks manajemen mutu syariah, pengelolaan lembaga BAZNAS Provinsi Jambi harus berorientasi kepada target hasil, pertumbuhan, keberlangsungan dan keberkahan. Dengan demikian pengelolaan zakat di BAZNAS Provinsi Jambi akan mewujudkan kenerja yang maksimal, sehingga bermuara pada tercapainya tujuan keberadaan lembaga BAZNAS, baik menurut UU, visi, misi lembaga maupun tercapainya hikmah dibalik pensyariatan zakat (maqâșid asysyarî'ah).

Manajemen mutu syariah menambahkan nilai pada kerangka manajemen lembaga BAZNAS Provinsi Jambi dengan menanamkan transparansi, kepercayaan, akuntabilitas, dan kredibilitas sebagaimana prinsip manajemen modern berdasarkan iman pokok (aqidah), hukum syariah, dan etika (akhlak). Berikut ini adalah prinsip dasar manajemen mutu berbasis syariah bagi BAZNAS Provinsi Jambi:

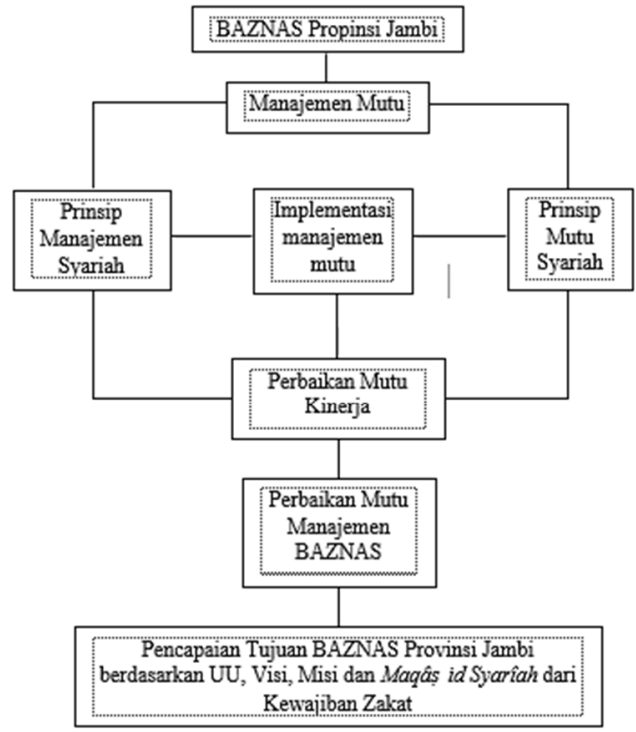

Gambar 1: Konstruksi Manajemen Mutu BAZNAS Zakat Berbasis Syariah 


\section{Indikator Keberhasilan Manajemen Mutu Syariah BAZNAS Provinsi} Jambi

Keberhasilan BAZNAS Provinsi Jambi dalam menerapkan manajemen mutu syariah dapat dilihat dari beberapa indikator berikut ini: 52

a. Aspek konteks, meliputi:

1) Memiliki pedoman kerja yang jelas dan memudahkan.

2) Memiliki standar manajemen secara tertulis.

3) Memiliki program yang relevan dengan kebutuhan dan perkembangan lembaga.

b. Aspek input, meliputi:

1) Rencana kegiatan.

2) Sumber Daya Manusia.

3) Anggaran.

4) Sistem manajemen mutu.

c. Aspek proses, meliputi:

1) Kesesuaian pelaksanaan dengan rencana program.

2) Kerjasama dalam pelaksanaan program.

3) Monitoring program.

4) Implementasi program.

d. Aspek produk, meliputi:

1) Efektifitas, dengan indikator:

a) Jumlah penghimpunan dana.

b) Jumlah dana tersalur.

c) Jumlah penerima manfaat.

d) Manfaat organisasi bagi masyarakat.

e) Sertifikasi sistem manajemen mutu.

2) Efisiensi, dengan indikator:

a) Biaya operasional lembaga zakat.

b) Laporan keuangan lembaga zakat.

3) Responsifitas, meliputi:

${ }^{52}$ Ahmad Juwaini, “Manajemen Mutu Lembaga Zakat”, dalam Sudirman, et.al., International Seminar on Zakat Financial Inclusiveness of the Poor: Beyond Microfinance (Malang: UIN-Maliki Press, 2015), h. 32. 
a) Kualitas pelayanan.

b) Tingkat kepercayaan masyarakat terhadap lembaga zakat.

\section{Implikasi Manajemen Mutu Syariah bagi BAZNAS Provinsi Jambi}

Zakat telah mengalami transformasi penuh dari ranah amalkaritas menjadi ranah pemberdayaan dan pembangunan umat dan negara. Dengan pengelolaan secara kolektif, melalui manajemen yang bermutu, zakat telah menjadi gerakan sosial-ekonomi yang independen dan mengizinkan adanya perbaikan kesejahteraan. Zakat yang dikelola melalui manajemen mutu syariah yang baik, menjadi strategis dalam konteks meningkatkan daya guna zakat sebagai pranata sosial-ekonomi. Dengan pengelolaan yang amanah dan efisien, serta berlandaskan pada nilai-nilai syariah, zakat bertransformasi dari kesalehan individual menjadi gerakan sosialekonomi. Dengan demikian, zakat menjadi semakin dekat dan efektif dengan tujuan utamanya sebagai instrumen penanggulangan kemiskinan.

Sistem pengelolaan zakat oleh BAZNAS Provinsi Jambi yang efektif disertai dengan manajemen pemberdayaan masyarakat secara terpadu, dapat mengantarkan kesejahteraan yang lebih tinggi kepada penerima zakat (mustahik), sehingga pada waktunya akan mampu beralih mencapai tingkat mandiri sebagai pemberi zakat (muzakki) baru, sebagaimana digambarkan berikut ini:

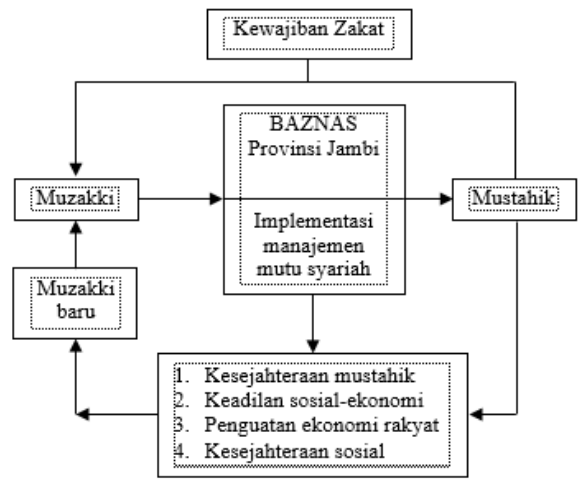

Gambar 2: Implikasi Penerapan Manajemen Mutu Syariah di BAZNAS Provinsi Jambi 


\section{Simpulan}

Zakat sebagai salah satu pilar dalam agama Islam memperlihatkan semangat mendukung perekonomian yang berkeadilan, dengan menitikberatkan pada mekanisme redistribusi dalam mengatasi berbagai kesenjangan ekonomi dan sosial. Pengelolaan zakat seperti halnya pengelolaan harta publik lainnya memiliki kesamaan karakter dan resikonya. Zakat akan memiliki positif terhadap perekonomian jika dikelola dengan manajemen mutu yang baik, sekaligus menerapkan nilai-nilai syariah di dalam manajemennya. Pengelolaan yang baik, menuntut adanya peran regulasi dan pengawasan yang efektif, organisasi pengelola zakat yang profesional dan sistem manajemen kelembagaan yang mendukung dan memiliki prinsip mutu yang baik. Manajemen zakat yang disertai dengan pendekatan mutu pada gilirannya akan dapat berkontribusi terhadap kesinambungan dan inklusivitas program pembangunan nasional, yang pada akhirnya akan mewujudkan kesejahteraan umat Islam di provinsi Jambi secara khusus dan masyarakat Indonesia secara umum.

\section{Daftar Pustaka}

'Abdullâh al-Muṣlih dan Șalâh as-Sawî. Mâ la Yasa'u al-Muslim Jahluhu. ar-Riyâd: Dar Isybiliya, cet. 1, 1419 H/1998 M.

'Abdullâh bin Muḥammad bin 'Abdurraḥmân bin Isḥâq al-Sheikh (Ed.). Lubâbut Tafsîr Min Ibni Kasîrr, Terj. Abdul Ghoffar, E.M dan Abu Ihsan Al-Atsari, Tafsir Ibnu Kasîr. Bogor: Pustaka Imam AsySyafi'i, 2004. Jilid. 6.

'Âdil ibn 'Âyid asy-Syamrî. “al-Jawdah asy-Syâmilah baina al-Manzûr al-Islâmî wa ar-Ru'yah al-Garbiyyah”, dalam al-Majallah al'Arabiyyah li Dimâni Jawdatitta'lîm al-Jâmi ‘̂̀, Vol. 19, 2015.

Abdul Halim Usman. Manajemen Strategis Syariah. Jakarta: Zikrul Hakim, 2015. 
Abû 'Ubaid al-Qâsim. Kitâb al-Amwâl, Terj. Setiawan Budi Utomo, Ensiklopedia Keuangan Publik: Zakat, Pajak. Depok: Gema Insani, 2006.

Ah\}mad Mukhtâr 'Umar. Mu jam al-Lugah al-'Arabiyyah al-Mu'âsirah. al-Qâhirah: 'Âlamul Kutub, Jilid I, 2008.

Ahamad Faosiy Ogunbado dan Asia Mus'ab al-Otaibi. “Is Quality Management an Islamic Value?”, dalam IOSR Journal of Business and Management. Vol. 8, Issue 3, Mar-Apr 2013.

Ahmad Ibrahim Abu Sinn. Manajemen Syariah: Sebuah Kajian Historis dan Kontemporer. Jakarta: PT. RajaGrafindo Persada, 2012.

Ahmad Juwaini. "Manajemen Mutu Lembaga Zakat”, dalam Sudirman, et.al., International Seminar on Zakat Financial Inclusiveness of the Poor: Beyond Microfinance. Malang: UIN-Maliki Press, 2015.

Ahmad Warson Munawwir. Kamus Arab-Indonesia Terlengkap. Surabaya: Pustaka Progressif, 1997.

Amir Syarifuddin. Ushul Fiqh. Jakarta: Prenada, 2008. cet. IV, Jilid. 2.

Asyraf Wajdi Dasuki (Ed.). Sistem Keuangan Islam: Prinsip dan Operasi. Jakarta: PT. RajaGrafindo Persada, 2015.

BAZNAS Provinsi Jambi. Laporan Tahunan Pengelolaan Zakat, Infak dan Sedekah Badan Amil Zakat Nasional (BAZNAS) Provinsi Jambi Tahun 2016 (Dokumen tidak diterbitkan).

BAZNAS Provinsi Jambi. Profil Badan Amil Zakat Nasional (BAZNAS) Provinsi Jambi Tahun 2016 (Dokumen tidak diterbitkan).

Boedi Abdullah dan Beni Ahmad Saebani. Metode Penelitian Ekonomi Islam (Muamalah). Bandung: CV. Pustaka Setia, 2014.

Budi Trianto. "Model Pemberdayaan Masyarakat Miskin Perkotaan oleh Institusi Zakat di Pekan Baru”. Disertasi, Pascasarjana Universitas Islam Negeri Sumatera Utara Medan, 2019. 
Dahlina Dahlan. “Bank Zakat: Pengelolaan Zakat dengan Konsep Bank Sosial Berdasarkan Prinsip Syariah", dalam Jurnal Ekonomi dan Bisnis Islam. Vol. 4, No. 2, Desember 2018.

Departemen Pendidikan Nasional. Kamus Bahasa Indonesia. Jakarta: Pusat Bahasa, 2008.

Dewan Redaksi Ensiklopedia Islam. Ensiklopedia Islam. Jakarta: PT. Ichtiar Baru Van Hoeve, 2003. Jilid V.

Didin Hafidhuddin dan Hendri Tanjung. Shariah Principles on Management in Practice. Jakarta: Gema Insani, 2006.

Edward Sallis. Manajemen Mutu Terpadu Pendidikan, terj. Ahmad Ali Riyadi dan Fahrurrozi. Jakarta: IRCiSoD, 2010.

Engkoswara dan Aan Komariah. Administrasi Pendidikan. Bandung: Alfabeta, 2011.

Hâfiz Ahmad 'Ujâj al-Karmî. al-Idârah fî 'asri ar-Rasûl: Dirâsah Târîkhiyyah li an-Nuzum al-Idâriyyah fî ad-Daulah al-Islâmiyyah al-Ûlâ. al-Qâhirah: Dârussalâm, 2006.

International Shari'ah Research Academic for Islamic Finance (ISRA). Sistem Keuangan Islam: Prinsip dan Operasi, ed. Asyraf Wajdi Dusuki. Jakarta: Rajawali Pers, 2015.

Kementerian Agama RI. Alquran dan Terjemahnya. Jakarta: PT. Sinergi Pustaka Indonesia, 2012.

Majduddîn Muhammad ibn Ya'qûb al-Fairuzzabâdî. al-Qâmûs alMuhît. al-Qâhirah: Dâr al-Hadîs, 2008.

Monzer Kahf. an-Nusûș al-Iqtiṣâdiyyah min al-Qurân wa as-Sunnah. Jeddah: Markaz an-Nasyr al-'ilmi, t.t.

Muhammad Zaki dan Bayu Tri Cahya. “Aplikasi Maqâsid asy-Syarî‘ah Pada Sistem Keuangan Syariah”, dalam Jurnal Bisnis dan Manajemen Islam. Vol. 3, Desember 2015. 
Nur Kholis, et.al. "Potret Filantrofi Islam di Daerah Istimewa Yogyakarta", dalam La-Raiba: Jurnal Ekonomi Islam, Vol. 7, No. 1, Juni 2013.

Oneng Nurul Bariyah. "Prinsip-Prinsip Syariah dalam Pengelolaan Zakat oleh Lembaga Pegelola Zakat", dalam Madania: Jurnal Kajian Keislaman. Vol. 17, No. 2, Desember 2013.

Pusat Kajian Strategis-Badan Amil Zakat Nasional dan STEI al-Ishlah Cirebon. Indikator Pemetaan Potensi Zakat (IPPZ). Jakarta: Pusat Kajian Strategis-Badan Amil Zakat Nasional, 2019.

Rhenald Kasali. “Organisasi Hidup yang Dipercaya dan Bermanfaat,” dalam Eri Sudewo, Manajemen Zakat: Tinggalkan 15 Tradisi Terapkan 4 Prinsip Dasar. Jakarta: Institut Manajemen Zakat, 2004.

Sri Kusriyah. "Politik Hukum Pengelolaan Zakat Sebagai Instrumen Penanggulangan Kemiskinan: Studi Kebijakan Pengelolaan Zakat di Provinsi Jawa Tengah". Disertasi, Program Pascasarjana Fakultas Hukum Universitas Islam Indonesia Yogyakarta, 2015.

Syauqî Ismâ‘îl Sahhâtih. at-Tatbîq al-Mu'âsir li az-Zakah, terj. Bahrun Abu Bakar dan Anshori Umar Sitanggal, Penerapan Zakat dalam Bisnis Modern. Bandung: CV. Pustaka Setia, 2007.

Undang-Undang Republik Indonesia Nomor 14 Tahun 1967 Tentang Pokok-Pokok Perbankan. Lembaran Negara Republik Indonesia Nomor 2842 Tahun 1967.

Undang-Undang Republik Indonesia Nomor 23 Tahun 2011 tentang Pengelolaan Zakat. Lembaran Negara Republik Indonesia Tahun 2011 Nomor 115.

Vithzal Rivai Zaenal. et.al., Islamic Management: Meraih Sukses Melalui Praktis Manajemen Gaya Rasulullah Secara Istiqomah. Yogyakarta: BPFE, 2013.

Wahbah az-Zuhailî. al-Fiqhul-Islâmî wa Adillatuhu, Terj. Fiqih Islâm wa Adillatuhu. Jakarta: Gema Insani Press, t.t. Jilid III. 
Muhammad Zaki, Amiur Nuruddin, Saparuddin Siregar

Yûsuf Qaraḍawî. Fiqh az-Zakâh, terj. Salman Harun, dkk, Hukum Zakat. Bogor: Pustaka Litera AntarNusa, 2011. 